\title{
Traditional knowledge and artisanal fishing technology on the Xingu River in Pará, Brazil
}

\author{
Mesquita, EMC. ${ }^{a *}$ and Isaac-Nahum, VJ. ${ }^{a}$ \\ a'Laboratório de Biologia Pesqueira e Manejo de Recursos Aquáticos, Centro de Ciências Biológicas, \\ Universidade Federal do Pará - UFPA, Av. Perimetral, 2651, Guamá, CEP 66077-530, Belém, PA, Brazil \\ *e-mail: esther_shekinah@hotmail.com
}

(With 5 figures)

Received: May 19, 2014 - Accepted: October 24, 2014 - Distributed: August 31, 2015

\begin{abstract}
In artisanal fishing, the techniques used by a community reflect the characteristics of the natural environment, in particular the distribution and availability of resources, as well as local traditions and customs. However, economic development may result in the loss of these traditions. The present study documents the fishing techniques used by the communities on the Xingu River in the Brazilian state of Pará (Maribel, Altamira, Belo Monte, Vitória do Xingu, Vila Nova, Senador José Porfírio, Porto de Moz, and Gurupá). Interviews were used to investigate traditional local knowledge and the distribution of the different fishing methods within the study area. The local fishers described the use of 12 different types of net, 10 hook and line techniques, and eight kinds of spearfishing. Free diving and scuba diving are also used for the capture of ornamental fish.
\end{abstract}

Keywords: fishing gear, traditional knowledge, Brazilian Amazon basin, small-scale fisheries.

\section{Etnoconhecimento e tecnologia da pesca artesanal no Rio Xingu, Pará, Brasil}

\begin{abstract}
Resumo
Na pesca artesanal, as modalidades de captura refletem as condições do meio ambiente e as tradições e costumes de uma comunidade. As artes de pesca utilizadas pelos pescadores refletem então, a disponibilidade de recursos e a história cultural de uma região. Contudo, o desenvolvimento econômico pode levar a perda dessas tradições. O objetivo deste trabalho é caracterizar os apetrechos de pesca utilizados pelos pescadores do rio Xingu, assim como seus conhecimentos acerca do uso dessas artes e a distribuição das mesmas ao longo do rio. Para isso foram realizadas visitas em diversas localidades ao longo do rio Xingu (Maribel, Altamira, Belo Monte, Vitória do Xingu, Vila Nova, Senador José Porfírio, Porto de Moz e Gurupá). Através de entrevistas com os pescadores obteve-se uma descrição das artes de pesca utilizadas na região. Os pescadores do rio Xingu utilizam 12 tipos diferentes de redes, 10 métodos de pesca com linha e anzol e 8 tipos distintos de artes de fisgar. Além do mergulho livre e com compressor utilizado na pesca ornamental.
\end{abstract}

Palavras-chave: apetrecho de pesca, conhecimento tradicional, bacia Amazônica Brasileira, pesca de pequena escala.

\section{Introduction}

Artisanal or small-scale fishing generally involves single individuals or small groups of fishers who use relatively simple equipment and techniques, and market their catches locally through intermediaries (Furtado, 1981; Bayley and Petrere, 1989; Pauly, 2006; Carvalho Júnior et al., 2011a). The small scale of this activity normally means that it has a reduced degree of impact on the environment. Artisanal fishing is the principal activity practiced in the Amazon basin, where it targets an enormous range of fish species, and provides an essential source of animal protein and economic income for riverside communities.

The diversity of fish species, considered to be the greatest of any freshwater system in the world, is at least partly responsible for the prominence of Amazonian artisanal fisheries in the national scenario (Furtado, 1981; Lowe-

McConnell, 1999; Santos and Santos, 2005), as well as at local markets (Cerdeira et al., 1997; Batista et al., 2004; Isaac and Almeida, 2011; Costa et al., 2013). Despite this diversity, the region's commercial fisheries exploit no more than $10 \%$ of the species known to occur in the region (Barthem and Fabré, 2004), and the 12 principal species account for two-thirds of the total catch volume landed at the principal ports located along the Amazon-Solimões River in northwestern Brazil (Batista et al., 2012).

Given its fundamental importance for the region's economy and the vast area covered by the Amazon basin, artisanal fisheries encompass a complex universe of actors and systems, with specific regional variations. The strategies used by the fishers in different regions are intimately related to the traditional knowledge of the 
distribution and habits of the fishery stocks accumulated over the generations. These characteristics reflect features of the landscape, habitats, climate, and the flood pulse of the river (Barthem and Fabré, 2004).

More than a third of the territory of the Brazilian state of Pará is formed by a major hydrographic network, centred on the Amazon River and its major tributaries, of which one of the largest is the Xingu River, on its right bank. Little data are available on the dynamics of the fisheries of the $\mathrm{Xingu}$, and most of the available information is found in environmental impact reports and the Basic Environment Plan produced during the legal licensing process for the construction of the Belo Monte hydroelectric power station.

River damming for the production of hydroelectric power has a range of impacts on the abundance and diversity of the local fish fauna, in particular an increase in fishery and natural mortality, the modification or inhibition of reproductive cycles, the reduction of the stocks of migratory and/or extremely rheophilic species, and the extinction of endemic species (Junk and Mello, 1990; Agostinho et al., 1992; Torloni, 1995). Overall, these changes tend to result in a reduction in fishery stocks, which may have a negative effect on productivity (Agostinho et al., 1994; Okada and Agostinho, 1996), with knock-on consequences for the lifestyle of the traditional local populations, which will need to adapt to the new conditions and the abundance and distribution of resources.

Fishing on the Xingu River is an ancient practice that predates the arrival of European colonists (Furtado, 1981). Furthermore, the fishing activity manifests itself as one of the least impactful possibilities, considering the region views, dominated by agricultural enterprises of small and large, deforestation for logging, grazing, and the existence of numerous mines (Sevá, 2005).

In the present day, this activity consists of two distinct modes: the production of food for human consumption and the live capture of ornamental fishes for the aquarium trade. The region's artisanal fishers use an ample variety of fishing gear and techniques, each appropriate to a specific situation and species or type of fish. The use of different techniques and the exploitation of fish stocks is based on traditional knowledge on the population dynamics of target species and the cyclical fluctuations in river conditions accumulated over the generations by the local riverside populations (Freitas and Rivas, 2006; Eletrobrás, 2008). The local fishermen live in the rural communities, village or urban centers and are offspring of indigenous and European (mainly Dutch) populations, or more recently from groups that migrated from northeastern or southern regions of Brazil, looking for land and livelihood opportunities. This miscegenation led to a "cabocla" society agro-fishery, whose habits reveal both the historical, economic, social and cultural process that came to the region as the characteristics and influences of the environment in which it developed (Furtado, 1993; Sevá, 2005).

Carvalho Júnior et al. (2009, 2011a, b) conducted the only previous study of the fishing technology used in the region of the Xingu River, focusing on the gear employed in the capture of ornamental fishes by both townsmen and members of the Juruna tribe resident in the Paquiçambá reservation.

Considering the social and environmental impacts of the construction of the Belo Monte hydroelectric dam on the river and the modifications of local fishery practices resulting from these impacts, there is considerable interest, from both scientific and social perspectives, in the inventory and preservation of this traditional knowledge. The present study describes the principal fishing techniques used by the residents of the traditional communities located along the Xingu and the variation in these practices found along the course of the river. This study contributes to the cultural memory of the region, recording the traditional knowledge and practices of the local artisanal fisheries for future generations.

\section{Material and Methods}

One of the major tributaries of the Amazon River, the Xingu is more than $2300 \mathrm{~km}$ long. Its principal tributary is the Iriri River, followed by the Bacajá, and many other rivers of substantial size flow into the Xingu before it discharges into the Amazon in the Brazilian state of Pará. The hydrographic basin of the Xingu covers a total area of more than $500,000 \mathrm{~km}^{2}$, and encompasses $24.5 \%$ of the state's territory, including all or part of the municipalities of São Félix do Xingu, Placas, Uruará, Medicilândia, Brasil Novo, Altamira, Anapú, Vitória do Xingu, Senador José Porfírio, and Porto de Moz (Belém, 2008).

In comparison with other Amazonian rivers, the Xingu presents a number of unique geological and hydrographic characteristics, such as a mean slope of $0.20 \mathrm{~m}$ per kilometer and an extremely rocky substrate throughout most of its course, which favors the presence of erosive channels, torrential runoff, and large numbers of rapids and waterfalls. These landscapes are dominated by "pedrais", rock formations that force the river to pass through anastomosed channels and complex bends, resulting in unique environments for fishing (Eletrobras, 2008). The fluvial regime of the middle and lower Xingu is characterized by a flood period between December and February, high water in March and April, an ebb period in May and June, and low water between August and November (Barthem and Fabré, 2004; Eletrobras, 2008).

The present study was based on 28 interviews with local fishers, all men with an average age of around 46 (from 21 to 70) who live along the Xingu in Maribel (3), Altamira (4), Belo Monte (4), Vitória do Xingu (3), Vila Nova (4), Senador José Porfírio (3), Porto de Moz (3), and Gurupá (4) (see Figure 1) and 82\% have in the fishery their income activity principal. The interviews, conducted between October, 2012 and May, 2013, were based on semi-structured questionnaires for the collection of detailed data on fishing gear and techniques, the habitats in which each technique is used, and the species targeted. Hooks were grouped in classes, with those of sizes 20 to 10 being considered small, 8 to 1 medium, and $1 / 0$ to $9 / 0$, large. 
With regard to the target species, the vernacular names of the different fish species provided by the interviewees were recorded (Appendix 1) and reported in italic font, and their scientific names were identified based on the report of the environmental impact study (EIA) of the Xingu River commissioned by Eletrobras (2008). Rather than a random selection of the participants, the interviews focused on the most experienced fishers in each community

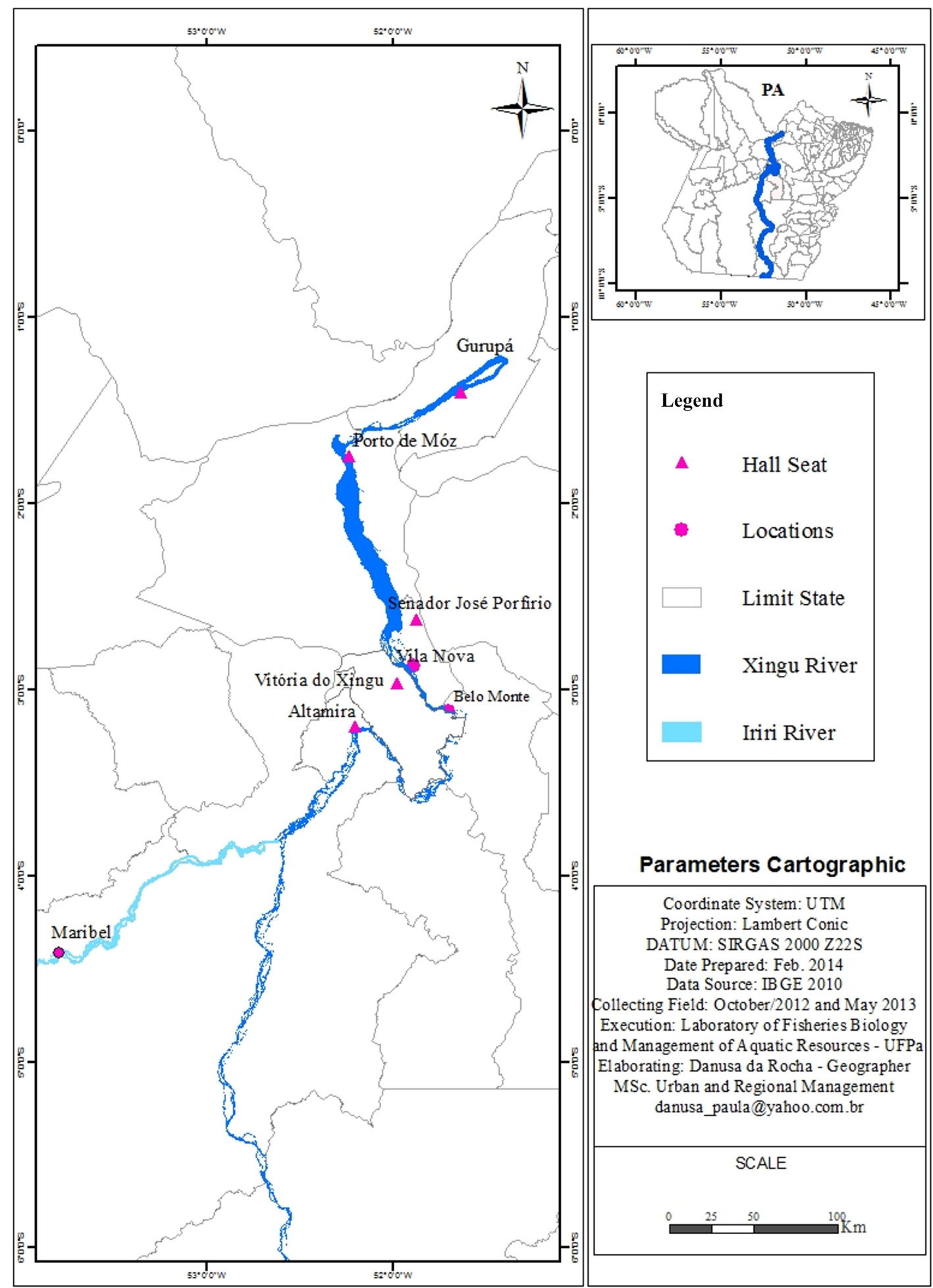

Figure 1. Map of the Xingu River in the Brazilian state of Pará, showing the communities in which the interviews were conducted. 
known to use the greatest diversity of gear, as indicated by each interviewee. The interviews were conducted in the residence of each fisher, and all the gear was photographed and measured for the production of technical drawings. The fishing gear was divided into four principal categories: nets, lines, spearfishing, and diving, adapted from Nédélec and Prado (1990). Local names of all gear were reported in Portuguese between quotation marks.

\section{Results}

\subsection{Fishing technology}

The artisanal fishers of the Xingu use all the different types of gear defined in this study. The names given to each type of equipment reflect either the target species or the manner in which the gear is used. The nets are woven from nylon or cotton, with the upper border containing a row of buoys, and the lower one, small pieces of lead, which help to sink the net. The position of the net in the water column can be modified by altering the number and size of the buoys, and the amount of lead.

Nylon lines are used with hooks of different sizes and a range of baits, depending on the target species. The spearfishing equipment includes bows and arrows, which represent an ancient, traditional practice dating to before the European colonization of the region. By contrast, the manual harvesting of fish by diving is the most modern technique found in the region, and is used primarily for the capture of ornamental fishes. An overview of the data collected for each type of fishing gear, and the techniques and target species, are summarized in Appendix 2, 3 and 4. The specific features of each type of gear are described below.

\subsubsection{Nets}

A total of 12 different types of fishing net were identified in the present study.

\subsubsection{Screen gillnet ("tela")}

A type of gillnet (see Figure 2a) used throughout the year, except during the closed season (between November and March), given that some prohibited species are captured frequently in nets. These nets may be placed in backwater habitats, such as lakes, swamps, streams, and river pools. These nets capture a number of commercial fish species, such as curimatã, pescada branca and tucunaré;

\subsubsection{Gillnet ("nylon")}

Similar to the "tela", used throughout the year in river channels, backwaters, and swamps, except during the closed season. These nets are used to catch large fishes, such as dourada and surubim;

\subsubsection{3. "Piabeira"}

Small net set close to the surface of the water and along the river margins, almost exclusively used for the capture of small bait fishes (known as piabas), used for line fishing or as a subsistence resource. This type of net is used throughout the year;

\subsubsection{4. "Flexeira"}

Net placed close to the surface of the water or in the middle of the water column, and used throughout the year, except for the closed season. These nets are set along the margins of rivers, backwaters, and streams to catch flexeira and other small-bodied fishes that are known as "salad" due to their low commercial value;

\subsubsection{Buoyed net ("culhão" or "bubuia")}

Net used in the middle of the water column or close to the surface (see Figure $2 b$ ). Two guide buoys permit the identification of the position of the net from the surface, for the retrieval of the catch. This type of net is placed

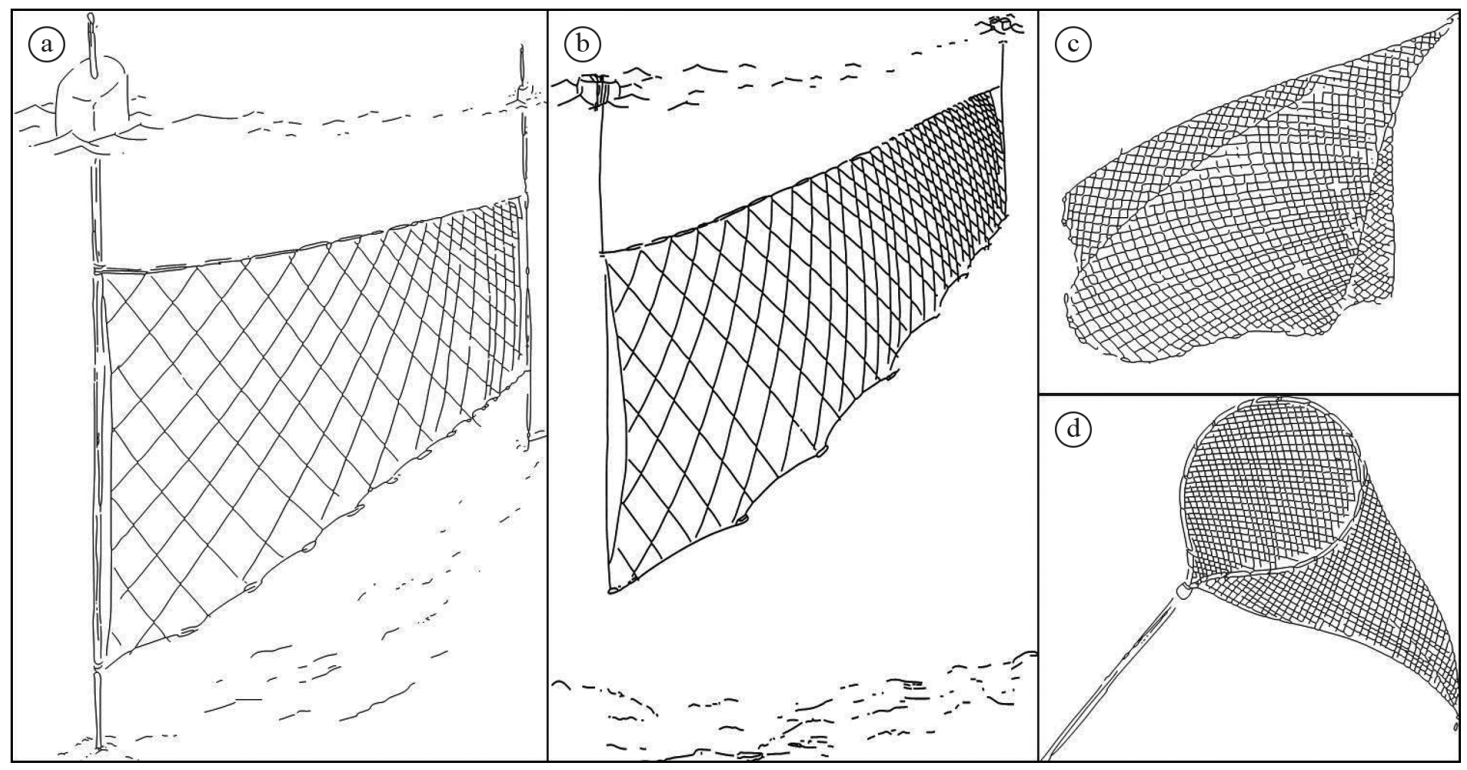

Figure 2. Fishing nets used on the Xingu River: (a) fixed net; (b) buoyed net (bubuia); (c) cast net; (d) hand net. 
in creeks and river margins during the high water period (March and April) to catch mapará and other pelagic species.

\subsubsection{Pirarucu net ("pirarucuzeira")}

Used in blackwater swamps (known as "igapó") during the high water period and on the river margins during low water to catch pirarucu and other large-bodied species;

\subsubsection{Catfish net ("douradeira")}

Used primarily to catch dourada, as well as filhote and piramutaba, during the dry season (June-October) at the mouth of the Xingu and in the Amazon River. One end of the net is dragged through the river by a boat, while the other is left to drift while the boat moves in the direction of the current;

\subsubsection{Seine ("rede de cerco")}

Seine nets are cast in a semi-circle formed using two canoes in the main channel of the river or in streams. Fish are herded towards the net by beating on the water with paddles;

\subsubsection{Seine trawl ("rede de arrasto de cerco")}

This type of seine net is weighted with additional lead to allow it to extend as far as the bottom of the river channel. One extreme of the net is tied to an anchor point on the bank, while the other is dragged through the water to encircle the fish using a canoe. This method is used to catch fishes such as jaraqui during the annual migration;

\subsubsection{Beach trawl ("rede de arrasto de praia")}

This type of net is loaded with additional lead to increase its weight. The net is dragged along the beaches which form on the margins of the river during the low water period (June-October). This type of net is used to capture ornamental fishes, principally plecos, but is rarely used;

\subsubsection{Cast net ("tarrafa")}

Cone-shaped nets with small lead weights arranged around the outer edge to increase their weight (see Figure 2c). The net is cast over shoals of fishes, forming a large circle in the air. This type of net is used almost exclusively for the capture of small bait fishes used for hook and line fishing on the river margins, but may also be used to catch piaba, jaraqui and curimatã;

\subsubsection{Hand net ("puçá de mão)}

Funnel-shaped net attached to a pole (see Figure 2d) used to catch ornamental fishes and other species that occur at depths of no more than $50 \mathrm{~cm}$. This net is used in shallow waters, at the margins of rivers and streams, and to probe under leaves.

\subsubsection{Hook and line}

Nylon lines are widely used for fishing on the Xingu to catch predator and frugivore species, principally during the closed season (November-March). As the numeration used by hook manufacturers does not follow a linear logic, most of the local fishers are unfamiliar with the formal specifications of this equipment. Large hooks are designated a number followed by $/ 0$, i.e., $1 / 0,2 / 0,3 / 0$ and so on for hooks of increasing size. Smaller hooks do not have this suffix, and the numeration decreases as hook size increases, although some brands of hooks follow a different classification system. In the present study, the smallest hook recorded was a size 20 , and the largest, a size 16/0. Ten different hook and line techniques were recorded in the present study, and are described below.

\subsubsection{Hand lines ("linhas de mão")}

Nylon line with a hook at the end and, normally, a small piece of lead to facilitate casting and the sinking of the hook. The other end of the line is held by the fisher when casting. This equipment is used to catch species such as pescada branca and tucunaré. Hand lines are also used to catch ornamental fishes, such as jacundás and rays, mainly in streams, but also in the main river;

\subsubsection{2. "Caniço"}

Home-made fishing pole made of bamboo (Bambuseidae), taboca (Guadua weberbaueri) (see Figure 3a). A nylon line is tied to one end of the pole, with a hook (generally small in size) and lead weight at the opposite extremity. These rods are used in swamps and marshes to catch species such as piau and pacu;

\subsubsection{Commercial fishing rod ("varas de pesca")}

Consisting of a graphite or glass fiber rod with a small reel and nylon line, which allows the hook to be cast over longer distances and facilitates its retrieval (see Figure 3b). This equipment is used occasionally by artisanal fishers, but more commonly in sport fishing;

\subsubsection{Unbarbed hooks ("anzol pé chato")}

These hooks are tied to a nylon line waxed with a substance extracted from alkaline batteries, which prevents it slipping in the hands of the fisher. To this art is preferably used carbon fiber line. This equipment is used to catch river turtles. In this technique, the fisher uses groundbait consisting of a sack containing pieces of cassava, which is placed in the water, together with a number of hooks baited with cassava (Manihot esculenta) or mucajá palm fruits (Acrocomia spp.). This technique is only used in the months following the turtles' nesting period (December-June), when they feed more intensively;

\subsubsection{5. "Gulepa"}

Consists of a nylon line with two hooks with a lead weight between them, which are separated by a spacer which prevents the nylon from tangling. The line is agitated in the water by the fisher, to attract the attention of predator fishes, thus avoiding the need for bait. This technique is used on the river throughout the year, and has no specific target, catching whatever fish happens to get hooked. However, this technique is work-intensive and relatively inefficient, so it is rarely used;

\subsubsection{Spoon ("currica")}

Artificial lure made of steel, lead or copper (see Figure $3 \mathrm{c}$ and $3 \mathrm{~d}$ ) which imitates the fusiform shape of a small fish, with one to three hooks attached, depending on the model. Different sizes are used according to the 


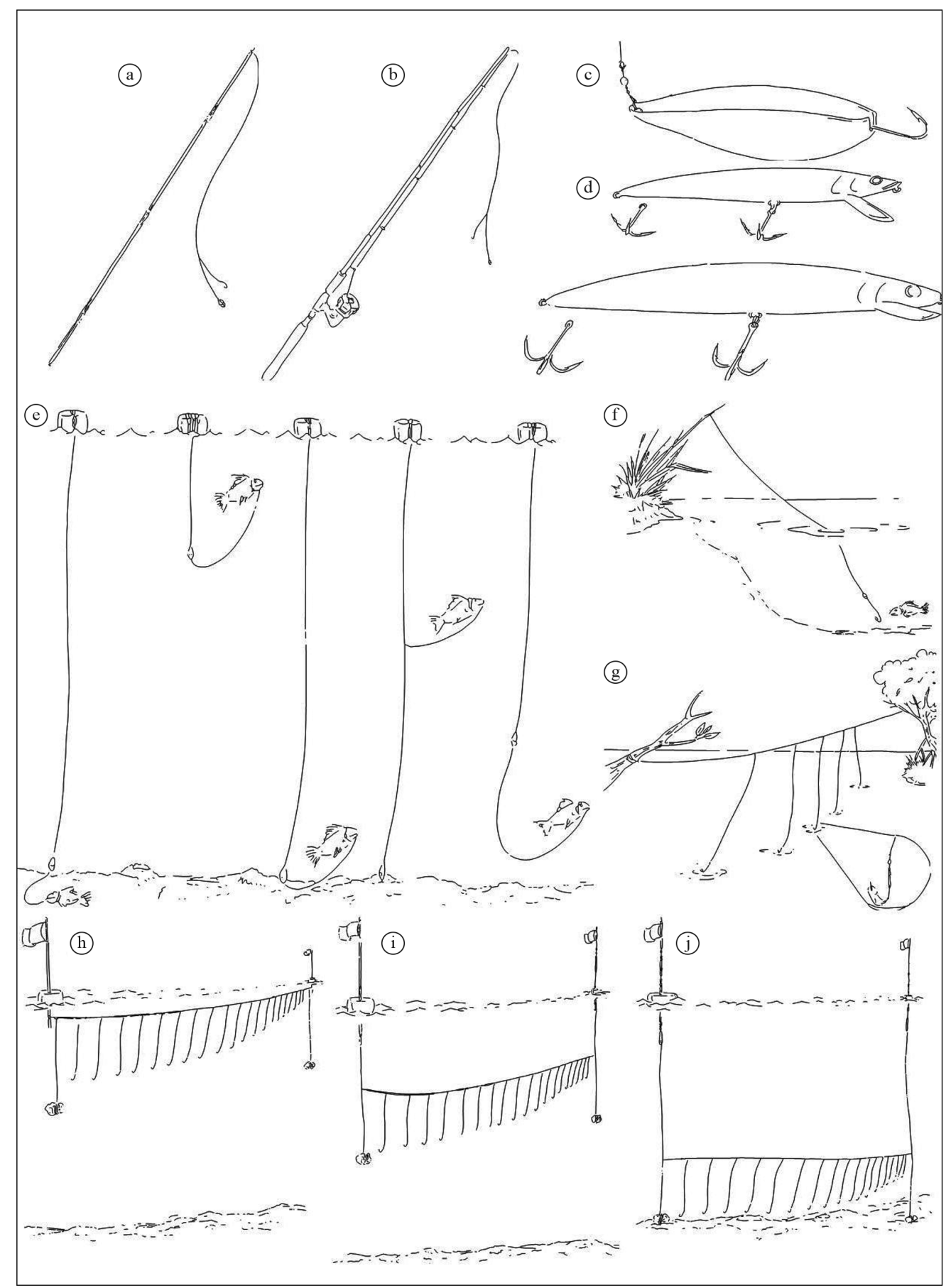

Figure 3. Types of fishing lines used on the Xingu River. (a) Homemade fishing pole (caniço); (b) fishing rod; (c) spoon; (d) artificial lures; (e) float lines used at different depths; (f) Camurim; (g) Atiradeira; (h) Surface espinhel; (i) Half-water espinhel; (j) Bottom espinhel.

target species. These lures are used in rivers throughout the year. The line is dragged behind a boat travelling at a slow speed, a practice known locally as to "curricar", and the sunlight reflecting off the lure attracts predators such as tucunarés, sardas, and piranhas. This technique can also be used without the lure, that is, plain hooks on a hand line, with the same target fish species;
3.1.2.7. Float lining ("boiete", "boieira" or "pesca de culhão")

Consists of a nylon line with a baited hook and lead weight at one end and a float at the other end, made from Styrofoam, a plastic bottle or a type of balsa wood, known as "boieira" (see Figure 3e). The line is cast into the main 
channel of the river, while the fisher waits in the canoe. When a fish has been hooked, the float begins to move. Used throughout the year, but preferentially during the rainy season. The principal species caught with this method are tucunaré, pescada branca, filhote, sarda, and barba-chata;

\subsubsection{Fixed line (“camurim")}

Nylon line with a baited hook and a lead weight at the end (see Figure $3 \mathrm{f}$ ). The other end of the line is tied to an anchor point in the vegetation of the river margin, with the hook resting near the bottom. While this type of line is used throughout the year, it is more common in the dry season. Used to catch large species such as pirarara, filhote, surubim, and, occasionally, alligator;

\subsubsection{9. "Atiradeira"}

Adaptation of the "espinhel", which consists of pieces of cord approximately $2 \mathrm{~m}$ long to which hooks are attached (see Figure $3 \mathrm{~g}$ ). The cords are stretched over the water, with the hooks just touching the surface. This type of line is used in swamps, in particular below rubber trees (Hevea brasiliensis) in March and April, when the seeds of this tree are falling into the water. The hooks are small and baited with rubber tree seeds to catch pacu and matrinxã;

\subsubsection{Long line (“espinhel”)}

Paternoster system, in which the main line has a series of secondary lines with hooks attached, the size of which depends on the target species. Normally used during the rainy season. May be used with live or dead bait. Target species include pirarara, filhote, dourada, and barba-chata. The main line is tied to a tree branch and set perpendicular to the margin. Close to the margin, smaller hooks are used, becoming progressively larger the further from the margin. These lines are usually set in the main channel of the river, at three different levels in the water column: on the surface (see Figure $3 \mathrm{~h}$ ), with buoys known as "guiadeiras" (guiders), in the middle of the column with both buoys and lead weights or "poita" (see Figure 3i), and on the bottom, with just two buoys at each extremity of the line (see Figure $3 \mathrm{j}$ ). In this case, the deeper the line, the larger the number of hooks used.

\subsubsection{Spearfishing equipment}

This category consists of techniques in which the fisher spears the catch in the water. Most of these techniques and the gear used are restricted to specific circumstances and species. As ancient and traditional techniques that require great skill, only experienced fishers engage in this type of activity. The different types of spearfishing recorded on the Xingu are described below.

\subsubsection{Bow and arrow}

An ancient type of equipment (see Figure 4a) dating back to the origins of civilization. On the Xingu, its use represents a legacy of the region's indigenous peoples. The bow is made of light and flexible wood, which permits it to bend into a semicircle. The arrows have a circular shaft with a sharp tip that may be either simple or bifurcated (known as a "sararaca") and lined with barbs. Bows and arrows are used to catch species such as tucunaré, curimatã, and acará. Using a bow and arrow to fish requires considerable visual acuity and skill. This method can be practiced during the day, but is more usually practiced at night with the help of a flashlight, on the margin of the river during the low water period, and in streams, swamps, and marshes during high water. This fishing technique is used by the older and more experienced fishers, and was observed mainly in the more isolated communities, being virtually extinct in the more urban areas;

\subsubsection{Trident (“zagaia")}

Wooden lance with a three-pointed barbed iron tip (see Figure 4b). The shaft is usually made of bamboo (Bambuseidae), ipê (Tabebuia spp.) or taboca (Guadua weberbaueri). The trident is used at night, at the margins of rivers and streams throughout the year, but preferentially during the dry season. Using a flashlight, the fisher locates a potential catch - generally tucunaré, ariduia, traíra or curimatã - before throwing the trident;

\subsubsection{Harpoon ("arpão")}

Wooden lance with a pointed tip to which a cord is attached (see Figure 4c), allowing the tip to separate from the shaft on hitting the target. Once the target is sighted, the harpoon is thrown at the fish, and when the shaft comes loose, the iron tip remains in the animal's body. The fish can then swim until exhaustion, when it is pulled into the boat by the cord. This technique is used in flooded marshes, streams, and river margins during the day, but more usually at night, principally during the high water period. The target species include pirarucu, filhote, and occasionally, alligator. Some fishers use harpoons only to help land exceptionally large fishes;

\subsubsection{4. "Tapuá"}

Wooden lance made of maçaranduba (Minusops huberi), itaúba (Mezilaurus itaúba) or ipê (Tabebuia spp.), with a pointed tip to which a cord is attached, allowing the tip to separate from the shaft when the target is hit, as in the case of the harpoon (see Figure 4d). The steel tip, known as a "tapuá" is small and unbarbed, and fits into a tin cup. This type of lance is used to capture Amazonian turtles throughout the year, but principally during the dry season, when the females lay their eggs, and are more vulnerable to capture. When the target individual is sighted, the fisher approaches in a canoe and throws the lance at the turtle's shell, pulls in the cord, and drags the turtle into the canoe. While this type of fishing is prohibited, it represents a cultural heritage. Most fishers claim to release the smaller individuals captured, apparently as an argument to justify the use of this type of gear;

\subsubsection{5. "Sararaca"}

Wooden lance with a U-shaped bifurcated tip (see Figure 4e), which is an adaptation of the bifurcated arrowhead. The shaft is made of flecheira (Gynerium sagittatum). 


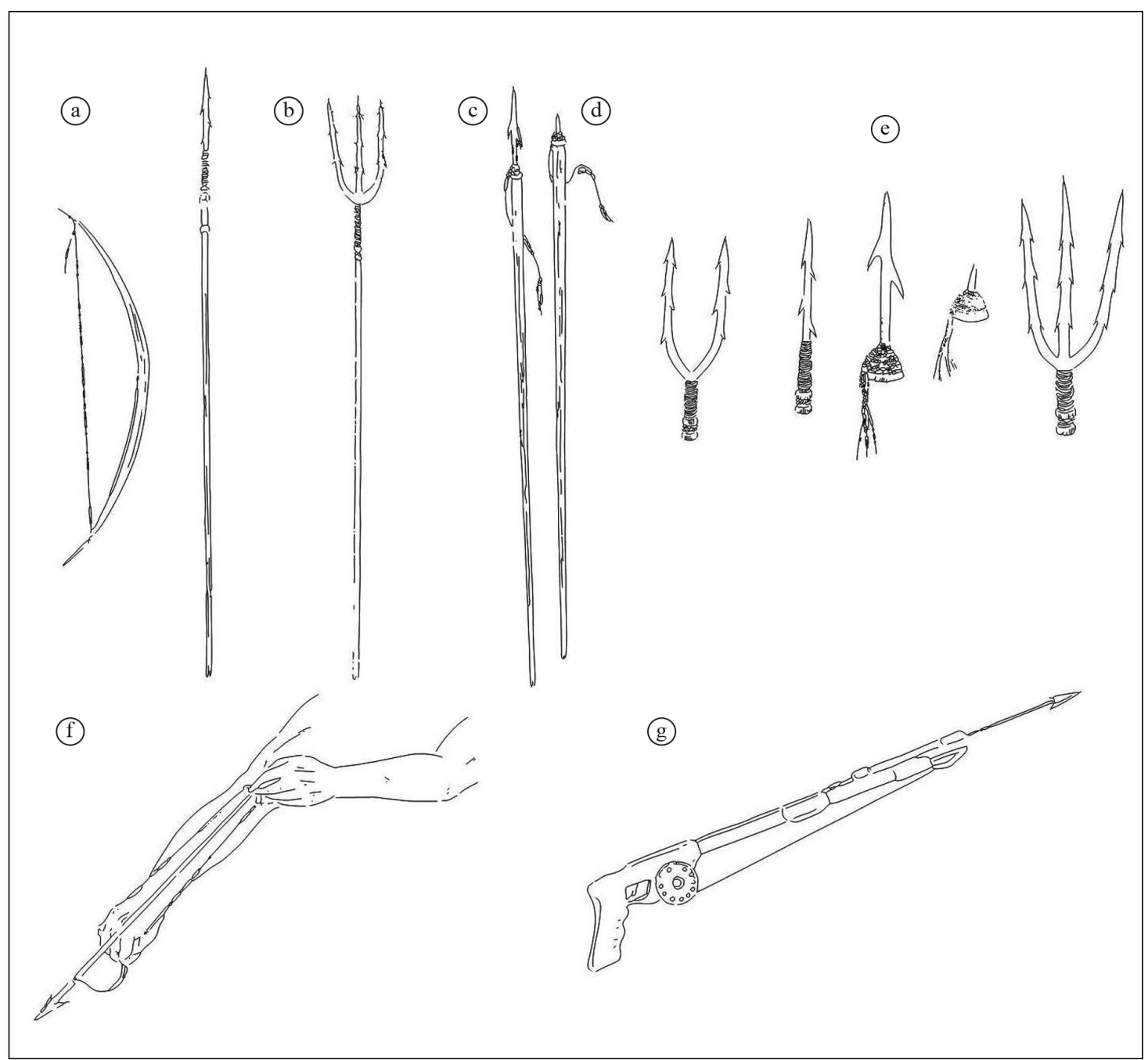

Figure 4. (a) Bow and arrow; (b) Trident; (c) Harpoon; (d) Tapuá; (e) Details of the different types of tip, showing (left to right), sararaca, single arrowhead, harpoon, tapuá, and trident; (f) catapult; (g) gas-powered speargun.

Used in a similar fashion to the trident, targeting species such as tucunaré and surubim;

\subsubsection{Catapult ("seta")}

Consists of a $60 \mathrm{~cm}$ harpoon made of iron, which is shot from the user's arm with a thick elastic line in a manner similar to an arrow from a bow (see Figure 4f). This type of spear is used throughout the year during nocturnal free diving with a flashlight, for the capture of tucunarés and other large-bodied fishes. However, this is a relatively rustic piece of equipment, and is uncommon;

\subsubsection{Wooden catapult ("espingarda de madeira")}

In this adaptation, a wooden support is used, which is similar to a miniature bow mounted on a wooden frame coupled to a firing mechanism, which allows the user to aim more easily and accurately than with a bow. This primitive type of speargun is used to fire the same iron harpoons as the catapult. Used throughout the year during nocturnal free diving to capture tucunaré and other fishes of large size. Despite being more sophisticated than the simple catapult, this version is still somewhat primitive, and is not widely used;

\subsubsection{Gas-powered speargun}

Powered by gas pressure, with lead projectiles, spearguns are used to catch large-sized fishes at night in the dry season by using a flashlight to search in relatively shallow waters (see Figure 4g). The principal target species are pirarara, surubim, and tucunaré.

\subsubsection{Diving}

These techniques involve the fisher diving under the water to spot and catch fish, in most cases ornamental species of the family Loricariidae, which are found on rocky substrates, and are highly valued on the international market. In recent years, however, diving has been used increasingly for the capture of tucunarés and other large fishes for human consumption, using a harpoon or speargun. Two types of diving are practiced in the study area: 


\subsubsection{Free diving}

Is practiced primarily during the dry season (low water), when the rocky outcrops are more exposed and fish can be found at relatively shallow depths. In general, the only equipment used is a diving mask and plastic containers tied to a belt, which are used to hold the fishes caught by the diver. The fishes are collected manually, using small sticks called "vaquetas", although in some cases, cast nets or hand nets may be used to capture the fishes. The target species vary according to market demands, but the principal ones are plecos, such as the little yellow, black cutia, and orange-tipped plecos;

\subsubsection{Airlining}

Practiced in deeper waters throughout the year. The equipment consists of an air compressor powered by a gasoline motor (see Figure 5), which is installed on the boat and connected to an airline with a mouthpiece at the end, through which the diver breathes. In deeper and/or more turbid waters, a flashlight is also connected to the motor by a wire that runs inside the air hose. The diver uses a mask and a weight belt to sink to the bottom, to which plastic containers are tied for the storage of the captured fishes. These divers may reach depths of more than $15 \mathrm{~m}$ in search of plecos. As in free diving, the fishes are captured manually or using cast and hand nets;

\subsubsection{Vaquetas}

Wooden sticks used by divers to capture fish. When a fish is located, the cast net is placed on one side of the rock substrate and the "vaqueta" is then introduced into the fissures in the rock, to dislodge the plecos, which flee in the direction of the net, where they are caught. Four principal types of "vaqueta" are used:
Type I - Short (approximately $30 \mathrm{~cm}$ ) and thin, used for the capture of the little yellow pleco;

Type II - Long (approximately $40 \mathrm{~cm}$ ) and flattened, used to capture zebra and black cutia plecos;

Type III - Very thin and approximately $30 \mathrm{~cm}$ long, used to retrieve old black plecos;

Type IV - Larger, around $40 \mathrm{~cm}$ long, used to capture cuiu. In this case, the "vaqueta" is hooked into the fish's fins and when it closes its fins, the diver retrieves the fish.

\subsection{Distribution of the different fishing methods within the study area}

The study area was characterized by marked variation in the distribution of the different types of fishing gear (see Table 1), with the greatest diversity and more traditional types of equipment being found in the communities furthest from the main towns, such as the villages of Senador José Porfírio, Belo Monte, and Vila Nova. In major urban centres, such as the town of Altamira, by contrast, there is a predominance of more efficient types of gear, such as gillnets. Hand lines are common at all sites, followed by fishing poles ("caniço"), long lines ("espinhel"), and tridents. In the majority of cases, however, the type of equipment was found in only one of the communities.

\section{Discussion}

In the Amazon basin, the distribution and ecology of fishery resources are determined by a set of environmental factors, including climate, habitat type, and the characteristics of the annual flood pulse. Local fishing communities are generally able to adapt to local conditions and resources,

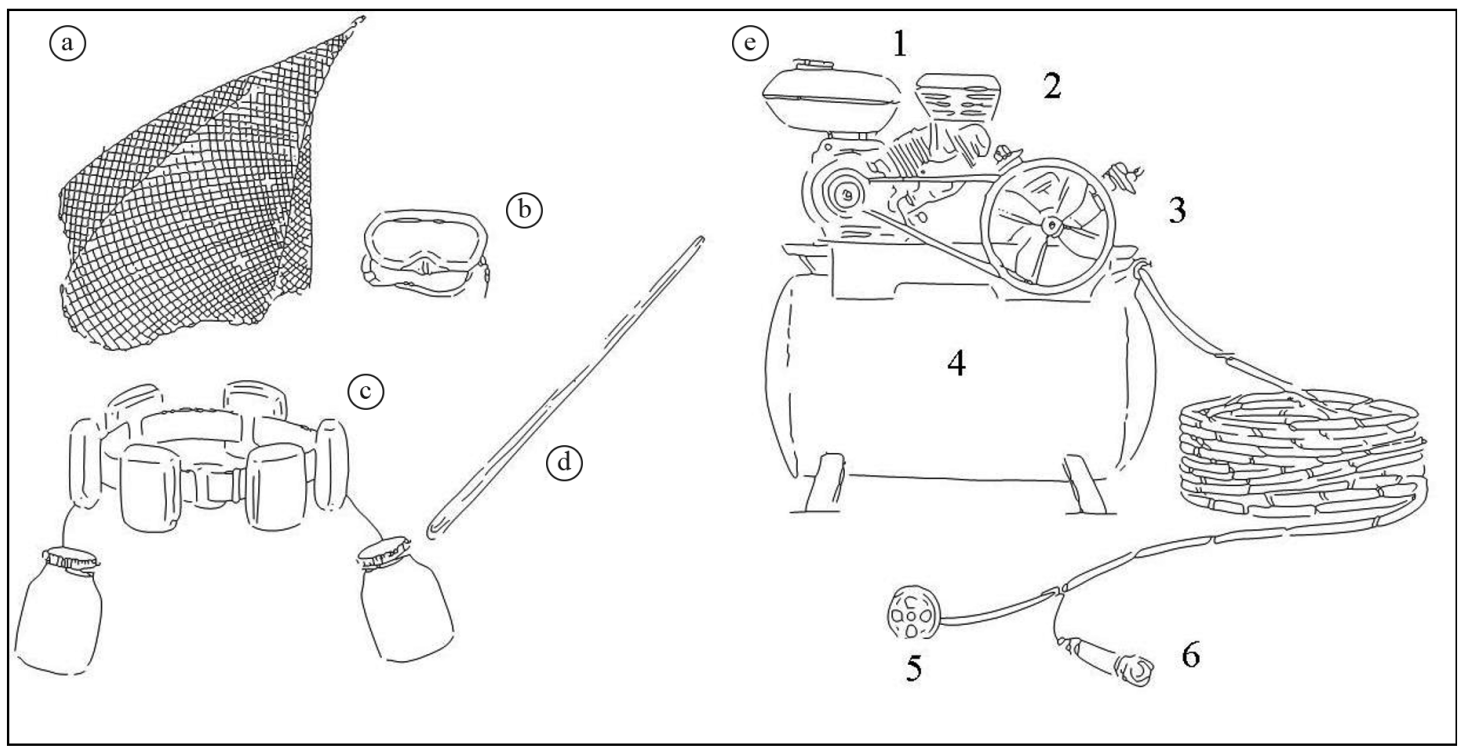

Figure 5. Diving equipment. (a) cast net; (b) mask; (c) weight belt with plastic containers; (d) vaqueta; (e) Compressor used to feed the airline: (1) fuel tank, (2) motor adapted to pump air and produce electricity, (3) valves connected to the airline, that control the flow of air to the diver, (4) air compressor, (5) mouthpiece, (6) flashlight. 
Table 1. Distribution of different types of fishing gear in the communities surveyed on the Xingu River in Pará, Brazil.

\begin{tabular}{|c|c|c|c|c|c|c|c|c|c|c|}
\hline & & Mar & Alt & BM & $\mathbf{V X}$ & SJP & $\mathbf{V N}$ & PM & Gur & $\begin{array}{c}\text { Total } \\
\text { number of } \\
\text { communities }\end{array}$ \\
\hline \multirow{12}{*}{ Nets } & Screen gillnet & $\mathrm{X}$ & $\mathrm{X}$ & $\mathrm{X}$ & $\mathrm{X}$ & $\bar{X}$ & $\mathrm{X}$ & $\mathrm{X}$ & $\mathrm{X}$ & 8 \\
\hline & Gillnet & & & $\mathrm{X}$ & & $\mathrm{X}$ & $\mathrm{X}$ & $X$ & $\mathrm{X}$ & 5 \\
\hline & Piabeira & & & & & $\mathrm{X}$ & & & & 1 \\
\hline & Flexeira & & & & & & $X$ & & & 1 \\
\hline & Buoyed net & & & & $\mathrm{X}$ & & & & & 1 \\
\hline & Pirarucu net & & & & & $\mathrm{X}$ & & $X$ & & 2 \\
\hline & Catfish net & & & & & & & & $\mathrm{X}$ & 1 \\
\hline & Seine & & & $\mathrm{X}$ & $\mathrm{X}$ & & & & & 2 \\
\hline & Seine trawl & & & & $\mathrm{X}$ & & & & & 1 \\
\hline & Beach trawl & & $\mathrm{X}$ & & & & & & & 1 \\
\hline & Cast net & $X$ & $X$ & $\mathrm{X}$ & & & & & & 3 \\
\hline & Hand net & & $\mathrm{X}$ & & & & $X$ & & & 2 \\
\hline \multirow{10}{*}{$\begin{array}{l}\text { Hook and } \\
\text { line }\end{array}$} & Hand line & $\mathrm{X}$ & $\mathrm{X}$ & $\mathrm{X}$ & $\mathrm{X}$ & $\mathrm{X}$ & $\mathrm{X}$ & $\mathrm{X}$ & $\mathrm{X}$ & 8 \\
\hline & Fishing pole & & $\mathrm{X}$ & $\mathrm{X}$ & $\mathrm{X}$ & $\mathrm{X}$ & $\mathrm{X}$ & & $\mathrm{X}$ & 6 \\
\hline & Fishing rod & & & $X$ & & & & & & 1 \\
\hline & Unbarbed hook & & & & & $\mathrm{X}$ & & & & 1 \\
\hline & Gulepa & & & & & $\mathrm{X}$ & & & & 1 \\
\hline & Spoon & & & & & $\mathrm{X}$ & & & & 1 \\
\hline & Float lining & & & $\mathrm{X}$ & & $\mathrm{X}$ & $\mathrm{X}$ & & & 3 \\
\hline & Camurim & & & & & & & & $\mathrm{X}$ & 1 \\
\hline & Long Line & & $\mathrm{X}$ & $X$ & $X$ & $X$ & & $X$ & $X$ & 6 \\
\hline & Atiradeira & & $\mathrm{X}$ & & & & & & & 1 \\
\hline \multirow{8}{*}{ Spearfishing } & Bow and arrow & & & & & $X$ & $X$ & & & 2 \\
\hline & Trident & & & $\mathrm{X}$ & $\mathrm{X}$ & $\mathrm{X}$ & $\mathrm{X}$ & $X$ & $\mathrm{X}$ & 6 \\
\hline & Sararaca & & & & & & & $X$ & & 1 \\
\hline & Harpoon & & & $\mathrm{X}$ & & $\mathrm{X}$ & $X$ & & $\mathrm{X}$ & 4 \\
\hline & Tapuá & & & & & $X$ & & & & 1 \\
\hline & Catapult & & & & & & $\mathrm{X}$ & & & 1 \\
\hline & $\begin{array}{l}\text { Wooden } \\
\text { catapult }\end{array}$ & & & & & & $\mathrm{X}$ & & & 1 \\
\hline & Speargun & & & $X$ & & & & & & 1 \\
\hline Diving & Vaqueta & $X$ & $\mathrm{X}$ & $\mathrm{X}$ & & & & & & 3 \\
\hline \multicolumn{2}{|c|}{$\begin{array}{l}\text { Number of different types } \\
\text { of gear recorded per site }\end{array}$} & 4 & 9 & 13 & 8 & 15 & 12 & 7 & & \\
\hline
\end{tabular}

adopting the strategies and gear most appropriate for each part of the year (Petrere Junior, 1978; Smith, 1979). In other words, their knowledge of the fish species they target enables them to direct their efforts to specific locations, where the species may be concentrated or more easily captured during a given period (Begossi, 2004).

The diversity of fishing techniques used in the Amazon basin reflects the inheritance of both indigenous practices and the European colonization and how they adapted to the environment (Veríssimo, 1895). The more traditional populations used cotton lines and spearing techniques, as well as other practices, such as the "palheta" (no longer found in the region), which consists of an apparatus which shoots arrows, similar to the catapult described above, the use of toxic plants, such as timbó (Sapindaceae), cururu-timbó
(Sapindaceae), and astacu (Hura crepitans), to poison the water, even this method has already prohibited, it is still used by some indigenous and fishers, harpoon tips and hooks made of bone, and the traditional bow and arrow (Furtado, 1981, 1993). In addition to these types of gear, Veríssimo (1895) notes that the original indigenous populations already used hand nets and a sack-shaped net made of cotton or tucum palm (Astrocaryum) leaves, which were less durable. However, these traditional methods did not have any major impact on fish stocks, and the catches were kept fresh or salted for local consumption.

In the 1970s and 1980s, federal law 5174, which provides tax incentives for the installation of businesses in the Brazilian Amazon basin, encouraged many commercial fisheries from other regions of the country to install operations 
in this region. This resulted in the introduction of modern equipment such as more powerful diesel-powered vessels with refrigeration systems and monofilament nylon line for making gillnets. These changes contributed to a major advance in the region's fishery potential (Pereira, 2004; Petrere Junior et al., 2007).

On the Xingu, traditional fishing equipment inherited from the region's original indigenous inhabitants can be found alongside more modern and effective technology. Carvalho Júnior et al. (2011b) reports that the inhabitants of the Paquiçambá reservation use gillnets, hand nets, hooks, and spears, as well as diving.

Gillnets were the only type of equipment recorded in all the communities surveyed in the present study. This is typical of fisheries in the Amazon region, and this equipment is used throughout the year in different types of habitat, such as backwaters, swamps, and lakes, both during the day and at night (Garcez, 2000; Batista et al., 2000). Gillnets are extremely efficient. The substitution of traditional cotton lines with nylon lines also increased the durability of these nets significantly.

Gillnets have also caused a number of conflicts among different fishery interests in the Amazon region, given that they are not only highly efficient, but also extremely unselective, capturing both adults and juveniles of different species indiscriminately (Isaac et al., 1994). The decline in fishery stocks is attributed primarily to the use of gillnets, and this has led some traditional communities in the Amazon region to regulate their use, and establish fishery agreements (Castro and McGrath, 2001; Castello et al., 2011).

In addition to gillnets, spearfishing techniques are commonly used to capture large catfishes, which are highly valued in the urban marketplace. The rapids on the upper Madeira River were previously thought to be the only place in the Amazon basin where large catfish are harvested using harpoons (Barthem and Goulding, 1997), although this practice was also confirmed on the Xingu River in the present study, indicating that the oldest fishing methods may still be common in regions that have been poorly surveyed.

The "pirarucu" is normally caught with a harpoon, which is the typical type of equipment used to capture this species (Smith, 1979). However, the fishers from Senador José Porfírio prefer to use cotton nets to capture this species, considering this method to be more effective than the harpoon. It is important to note that this implies the loss of traditional knowledge, given that the use of the harpoon requires expertise and experience, which may be dying out in the younger generations of local fishers.

The ongoing colonization of the Amazon region extends far beyond its explicit economic and social changes, given that the modernization of fishing techniques and gear modifies fishery patterns and alters the relationship between the local communities and their fish stocks (Veríssimo, 1895). These changes were initially quite subtle, but have become increasingly consolidated over time, with traditional practices being adapted to the new realities of the region's development.
It seems likely that empirical knowledge of the region's fish fauna, related to the understanding of aquatic ecosystems by the human populations that depend on their resources, may suffer profound changes in the future. In particular, the construction of the Belo Monte hydroelectric power station will almost certainly have fundamental impacts on the composition of the local fish communities. Reservoir environments are relatively unaffected by the natural flood pulse that characterizes most Amazonian rivers. The diversity of the aquatic environments in this region is at least partly determined by this cyclical fluctuation in river levels. The reservoirs formed by the construction of the dams on the Xingu will result in the formation of large areas of lentic habitat, which did not exist previously in the region. However, a long stretch of the Great Bend will continue to have a greatly reduced flow, creating permanent low water conditions, which would favor the using of the fishing techniques that are currently restricted to the dry season.

In this situation, it seems likely that many of the more traditional fishing methods will become increasingly less efficient, and a smaller selection of methods - those best adapted to the news conditions - will continue in use. In the Itaipu reservoir in southern Brazil, gillnets are used more intensively than the hooks and lines that were used to catch large catfish prior to the damming of the Paraná River. This change reflects the modification of the fish community of the area of the reservoir, from which at least 20 species have disappeared, as well as the drastic reduction in the size of the fishes caught (Agostinho et al., 1999).

A similar situation has been recorded in the Tucuruí reservoir on the Tocantins River in the southeastern Amazon basin, where fishing techniques currently include nets, poles, hand lines, paternoster lines, shrimp traps, and harpoons (Cintra et al., 2009). Prior to the construction of the Tucuruí dam, a greater diversity of fishing techniques was found in the area, including blockades for mapará, mobile weirs made of stakes of light wood called "paris", which can be used in a number of different ways, fixed or drifting gillnets, cast nets, paternoster lines and, occasionally, harpoons, tridents, and bows-and-arrows (Mérona et al., 2010).

In general, the more traditional fishing methods now tend to be increasingly less common and restricted to the more isolated communities, relatively distant from major urban centers. The demand for animal protein in these centers inevitably favors the use of more modern and efficient methods. Fish is one of the principal sources of animal protein in the towns and cities located along rivers of the Amazon basin (Bayley \& Petrere, 1989; Petrere Junior, 1991; Isaac and Almeida, 2011). Faced with the demand from local markets, local fishers tend to abandon the more traditional and selective methods, in favor of gillnets, which permit larger catches of a greater variety of species, and thus greater profits.

It is important to note that fishing in the Amazon region is an arduous activity, which demands both hard physical labor and exposure to the strong equatorial sun, 
resulting in a range of health problems, such as sunburn, skin cancer, and back pain. In the specific case of airline diving, conditions on the Xingu are especially insalubrious. The inadequate use of compressors, in particular the lack of filters, results in the diver breathing air infused with exhaust fumes and other substances, causing respiratory problems and pneumonia. Long periods underwater and inadequate decompression may cause rheumatism, temporary paralysis and loss of vision, and hearing problems. Additional risks include explosions, airline tangles, and other underwater accidents, which can often be fatal (Carvalho Júnior et al., 2009, 2011a).

While reservoirs may often result in an initial increase in fishery productivity in comparison with the original river, this is due to changes in species composition, with larger, more valuable species being substituted by smaller, less profitable types of fish that demand modifications of fishing strategies (Agostinho et al., 1994). Given this, changes in the composition of catches and the diversity of fishing methods should be monitored systematically on the Xingu over the coming years, accompanying the implantation of the Belo Monte dam. The effects of this process are likely to have profound cultural and socio-economic impacts on the local populations that depend on fishery resources. Detailed investigation of the adaptations of local fishing communities to the new environmental conditions established by the damming of the river will be essential to mediate the over-exploitation of stocks and related socio-environmental impacts.

\section{Acknowledgements}

We are grateful to the entities that financed this research - CAPES, Leme Engineering Ltd., FADESP, and Norte Energia. We would also like to thank our friend Marcos Vinicius da Silva for the drawings of the fishing equipment, and Danusa da Rocha for producing the map.

\section{References}

AGOSTINHO, A.A., JÚLIO JÚNIOR, H.F. and PETRERE JUNIOR, M., 1994. Itaipu reservoir (Brazil): impacts of the impoundment on the fish fauna and fisheries. In COWX, I.G. Rehabilitation of freshwater fisheries. Bodman: Fishing News Books. p. 171-184.

AGOSTINHO, AA., JÚLIO JÚNIOR, HF. and BORGHETTI, JR., 1992. Considerações sobre os impactos dos represamentos na ictiofauna e medidas para sua atenuação. Um estudo de caso: reservatório de Itaipu. Revista Unimar, vol. 14, p. 89-107.

AGOSTINHO, AA., OKADA, EK. and GREGORIS, J., 1999. A pesca no reservatório de Itaipu: aspectos socioeconômicos e impactos de represamento. In HENRY, R. Ecologia de reservatórios: estrutura, função e aspectos sociais. Botucatu: FUNDIBIO/ FADESP. p. 281-319.

BARTHEM, R. and GOULDING, M., 1997. Os bagres balizadores: ecologia, migração and conservação de peixes amazônicos - Tefé. Tefé, AM: Sociedade Civil Mamirauá; Brasília: CNPq. 140 p.
BARTHEM, RB. and FABRÉ, NN., 2004. Biologia e diversidade dos recursos pesqueiros da Amazônia. In RUFFINO, M. L. $A$ pesca e os recursos pesqueiros na Amazônia Brasileira. Manaus: Ibama/ProVárzea. p. 17-51.

BATISTA, VS., FREITAS, CEC., SILVA, A J.I. and FREIREBRASIL, D., 2000. The fishing activity of the river people in the floodplain of the Central Amazon. In JUNK, W.J., PIEDADE, M T.F. and SOARES, MGM. The Central Amazon Floodplain: actual use and options for sustainable management. Leiden: Backhuys Publishers/The Netherlands. p. 417-431.

BATISTA, VS., ISAAC, VJ. and FABRÉ, NN., 2012. A Produção desembarcada por espécie e sua variação por macrorregião Amazônica. In BATISTA, VS. Peixes e pesca no Solimões-Amazonas: uma avaliação integrada. Brasília: Ibama/ProVárzea. $276 \mathrm{p}$.

BATISTA, VS., ISAAC, VJ. and VIANA, JP., 2004. Exploração e manejo dos recursos pesqueiros da Amazônia. In RUFINO, M. L. A pesca and os recursos pesqueiros na Amazônia brasileira. Manaus: ProVárzea/Ibama. p. 63-152.

BAYLEY, P. and PETRERE, M., 1989. Amazon fisheries: assessment current status and management options. Canadian Special Publications Fisheries and Aquatic Science, vol. 106, p. 385-398.

BEGOSSI, A., 2004. Áreas, pontos de pesca, pesqueiros e territórios na pesca artesanal. In BEGOSSI, A. Ecologia de Pescadores da Mata Atlântica e da Amazônia. São Paulo: Hucitec. p. 89-148.

Belém. Secretaria de Estado de Pesca e Aqüicultura - SEPAQ, 2008. Diagnóstico da pesca e da aquicultura no Estado do Pará. Vol. 2. 156 p. Mimeo.

CARVALHO JÚNIOR, JR., CARVALHO, N.S.S., NUNES, JLG, CAMOES, A., BEZERRA, MF, SANTANA, A.R. and NAKAYAMA, L., 2009. Sobre a pesca de peixes ornamentais por comunidades do rio Xingu, Pará-Brasil: Relato de Caso. Boletim do Instituto de Pesca, vol. 35, p. 521-530.

CARVALHO JÚNIOR, JR., FONSECA, M.J.C., SANTANA, A.R., NAKAYAMA, L., 2011a. O conhecimento etnoecológico dos pescadores yudjá, Terra Indígena Paquiçamba, Volta Grande do Rio Xingu, PA. Tellus, vol. 11, no. 21, p. 123-147.

CARVALHO JÚNIOR, JR., ZACARDI, D.M., BITTENCOURT, SCS.; BEZERRA, M F.C. and NUNES, JLG. 2011b. Apetrechos de pesca ornamental utilizados pelos Juruna da Terra indígena Paquiçamba (Pará, Brasil). Boletim Técnico-Científico do CEPNOR, vol. 11, p. 71-79

CASTELlO, L., MCGRATH, DG. and BECK, PSA., 2011. Resource sustainability in small-scale fisheries in the Lower Amazon floodplains. Fisheries Research, vol. 110, no. 2, p. 356364. http://dx.doi.org/10.1016/j.fishres.2011.05.002.

CASTRO, F. and MCGRATH, D., 2001. O manejo comunitário de Lagos na Amazônia. Parcerias Estratégicas, vol. 12, p. 113-126.

CERDEIRA, RGP., RUFFINO, ML. and ISAAC, VJ., 1997. Consumo de pescado e outros alimentos pela população ribeirinha do lago grande de Monte Alegre, PA - Brasil. Acta Amazonica, vol. 27, no. 3, p. 213-228. http://dx.doi.org/10.1590/1809-43921997273228.

CINTRA, IHA., JURAS, AA., SILVA, KCA., TENÓRIO, GS. and OGAWA, M., 2009. Apetrechos de pesca utilizados no reservatório da usina hidrelétrica de Tucuruí (Pará, Brasil). Boletim TécnicoCientifico do CEPNOR, vol. 9, p. 67-79.

COSTA, TV., SILVA, RRS., SOUZA, JL., BATALHA, OS. and HOSHIBA, MA., 2013. Aspectos do consumo e comércio de 
pescado em Parintins. Boletim do Instituto de Pesca, vol. 39, no. 1, p. 63-75.

Eletrobras, 2008. Diagnóstico - estudo de impacto ambiental sobre a Fauna e Flora da Região do Médio Rio Xingu - UHE Belo Monte. Rio de Janeiro: Eletrobras. 433 p. Available from: $<$ http://www.ibama.gov.br/licenciamento/>. Access in: 15/10/2013.

FREITAS, C E.C. and RIVAS, A.A.F., 2006. A pesca e os recursos pesqueiros na Amazônia Ocidental. Ciência e Cultura, vol. 58, no. 3 , p. 30-32.

FURTADO, LG., 1981. Pesca artesanal: um delineamento de sua história no Pará. Boletim do Museu Paraense Emílio Goeldi, vol. 79 , p. 1-50.

FURTADO, LG., 1993. Pescadores do rio Amazonas. Um estudo antropológico da pesca ribeirinha numa área amazônica. Belém: Museu Paraense Emilio Goeldi. 486 p.

GARCEZ, DS., 2000. A pesca de ribeirinhos em ambientes de várzea de uso comum, Baixo Solimões, Amazônia Central. Manaus: Instituto Nacional de Pesquisas da Amazônia; Universidade Federal do Amazonas. 89 p. Dissertação de mestrado.

ISAAC, V.J. and ALMEIDA, M.C., 2011. El consumo de pescado en la amazonía brasileña. Roma: FAO. 43 p. COPESCAALC Documento Ocasional, no. 13.

ISAAC, VJ., ROCHA, V L.C. and MOTA, S.Q.C., 1994. Ciclo reprodutivo de algumas espécies de peixes comerciais do Médio amazonas. Brasília: IARA/IBAMA. Research Report.

JUNK, WJ. and MELLO, JASN., 1990. Impactos ecológicos das represas hidrelétricas na bacia Amazônica Brasileira. Tübinger Geographische Studien, vol. 95, p. 367-385.

LOWE-MCCONNELL, R., 1999. Estudos ecológicos de comunidades de peixes tropicais. São Paulo: EDUSP. 534 p.

MÉRONA, B., JURAS, AA., SANTOS, GM. and CINTRA, IHA., 2010. Os peixes e a pesca no baixo Rio Tocantins: vinte anos depois da UHE Tucuruí. Brasília: Eletrobras Eletronorte. 208 p.

NEDELEC, C. and PRADO, J., 1990. Definition and classification of fishing gear categories. Roma: FAO Fisheries. 107 p. Technical Paper 222.

OKADA, EK. and AGOSTINHO, AA., 1996. Catch and effort data and the management of the commercial fisheries of Itaipu reservoir in the upper Paraná river, Brazil. In COWX, I.G. Stock assessment in inland fisheries. London: Fishing News Books. p. 154-161.

PAULY, D., 2006. Major trends in small-scale marine fisheries, with emphasis on developing countries, and some implications for the social sciences. Maritime Studies, vol. 4, no. 2, p. 7-22.

PEREIRA, HS., 2004. Iniciativas de cogestão dos recursos naturais da várzea - Estado do Amazonas. Manaus: GTZ/Ibama.

PETRERE JUNIOR, M., 1978. Pesca e esforço de pesca no estado do Amazonas II. Locais, aparelhos de captura e estatística de desembarque. Acta Amazonica, vol. 8, no. 3, p. 439-454.

PETRERE JUNIOR, M., 1991. As comunidades humanas ribeirinhas da Amazônia e suas transformações sociais. In DIEGUES, A. C. S. (Ed.). Populações humanas, rios e mares da Amazônia: coletânea de trabalhos apresentados no IV Encontro de Ciências Sociais e o Mar no Brasil, 6 a 9 de junho de 1990. São Paulo: Programa de Pesquisa e Conservação de Áreas Umidas no Brasil. p. 31-68. Coletânea de trabalhos apresentados no IV Encontro de Ciências Sociais e o Mar no Brasil.

PETRERE JUNIOR, M., BATISTA, V.S., FREITAS, C.E.C., ALMEIDA, O.T. and SURGIK, A.C.S., 2007. Amazônia: ambientes, recursos e pesca. In O setor pesqueiro na Amazônia: análise da situação atual e tendências do desenvolvimento da indústria da pesca. Manaus: Editora da Universidade Federal do Amazonas. Projeto Manejo dos Recursos Naturais da Várzea, IBAMA/ProVárzea. p. 11-17.

SANTOS, GM. and SANTOS, ACM., 2005. A sustentabilidade da pesca na Amazônia. Estudos Avançados, vol. 19, no. 54, p. 165-182. http://dx.doi.org/10.1590/S0103-40142005000200010.

SEVÁ, O., 2005. Povos indígenas, as cidades, e os beiradeiros do rio Xingu que a empresa de eletricidade insiste em barrar. In SEVÁ FILHO, A. O. (Org.). Tenotã-Mõ: alertas sobre as consequências dos projetos hidrelétricos no rio Xingu. Berkeley: International Rivers Network. p. 29-54.

SMITH, NJH., 1979. A pesca no rio Amazonas. Manaus: CNPq/ INPA. $154 \mathrm{p}$.

TORLONI, CEC., 1995. Manejo dos recursos pesqueiros nos reservatórios da CESP. In Seminário sobre a Fauna Aquática e o Setor Elétrico Brasileiro, 1995, Rio de Janeiro: COMASE/ Eletrobrás. Caderno V.

VERÍSSIMO, J., 1895. A pesca na Amazônia. Rio de Janeiro: Livraria Clássica Francisco Alves. 206 p. 
Appendix 1. Common and scientific names for the fish and others species mentioned in the text.

\begin{tabular}{|c|c|}
\hline Common name & Scientific name \\
\hline Acará & $\begin{array}{l}\text { Retroculus xinguensis (GOSSE), Caquetaia spectabilis (STEINDACHNER), } \\
\text { Satanoperca sp }\end{array}$ \\
\hline Alligator & $\begin{array}{l}\text { Caiman crocodilus (LINNAEUS); Melanosuchus Niger (SPIX); Paleosuchus } \\
\text { palpebrosus (CUVIER) }\end{array}$ \\
\hline Amarelo/apapa/sarda & Pellona spp. \\
\hline Amazonian turtle & Podocnemis expansa (SCHWEIGGER) \\
\hline Aracu/piau & Anastomidae \\
\hline Ariduia/ariru & Semaprochilodus brama (VALENCIENNES) \\
\hline Arraia & Potamotrygon spp. \\
\hline Aruanã/ uruanã & Osteoglossum bicirrhosum (CUVIER) \\
\hline Barba-chata/ piranambu & Pinirampus pirinampu (SPIX \& AGASSIZ) \\
\hline Bararuá & Uaru amphiacanthoides (HECKEL) \\
\hline Bicuda & Boulengerella spp. \\
\hline Black cutia pleco & Scobinancistrus sp \\
\hline Braço de moça & Platystomatichthys sturio (KNER) \\
\hline Branquinha/ mocinha & Potamorhina spp. \\
\hline Cachorra & Hydrolycus armatus (JARDINE) \\
\hline Cará-açu & Astronotus crassipinnis (HECKEL) \\
\hline Carapitinga & Lutjanus sp. \\
\hline Caratinga & Geophagus altifrons (HECKEL) \\
\hline Common pleco & Peckoltia vittata (STEINDACHNER) \\
\hline Cuiu & Doradidae \\
\hline Curimatã & Prochilodus nigricans (SPIX \& AGASSIZ) \\
\hline Dourada & Brachyplatystoma rousseauxii (CASTELNAU) \\
\hline Erana/flexeira & Hemiodus spp. \\
\hline Fidalgo & Ageneiosus inermis (LINNAEUS) \\
\hline Filhote/piraíba & Brachyplatystoma filamentosum (LICHTENSTEIN) \\
\hline Jacundá & Crenicichla spp. \\
\hline Jandiá & Leiaurius marmoratus (GILL) \\
\hline Jaraqui & Semaprochilodus spp. \\
\hline Jau & Zungaro zungaro (HUMBOLDT) \\
\hline Jeju & Hoplerythrinus unitaeniatus (SPIX \& AGASSIZ) \\
\hline Little yellow pleco & Baryancistrus spp. \\
\hline Mapará & Hypophthalmus marginatus (VALENCIENNES), H. fimbriatus (KNER) \\
\hline Matrinxã & Brycon cephalus (GÜNTHER) \\
\hline Old black pleco & Ancistrus ranunculus (MULLER, RAPP PY-DANIEL \& ZUANON) \\
\hline Orange tipped pleco & $\begin{array}{l}\text { Baryancistrus chrysolomus (RAPP PY-DANIEL, ZUANON \& RIBEIRO DE } \\
\text { OLIVEIRA) }\end{array}$ \\
\hline Pacu & Mylossoma spp. \\
\hline Pataca & Tetragonopterus argenteus (CUVIER) \\
\hline Pescada branca & Plagioscion squamosissimus (HECKEL) \\
\hline Piaba & Astianax spp. \\
\hline Pintado & Pseudoplatystoma fasciatum (LINNAEUS) \\
\hline Piramutaba & Brachyplatystoma vaillantii (VALENCIENNES) \\
\hline Piranha & Serrasalmidae \\
\hline Piranha preta & Serrasalmus rhombeus (LINNAEUS) \\
\hline Pirapitinga & Piaractus brachypomus (CUVIER) \\
\hline Pirarara & Phractocephalus hemioliopterus (BLOCH \& SCHENEIDER) \\
\hline Pirarucu & Arapaima gigas (SCHINZ) \\
\hline
\end{tabular}


Appendix 1. Continued...

\begin{tabular}{ll}
\hline \multicolumn{1}{c}{ Common name } & \multicolumn{1}{c}{ Scientific name } \\
\hline Sardinha & Triportheus spp; Anchovia spp; Anchoviella spp; \\
Surubim & Pseudoplatystoma punctifer (CASTELNAU) \\
Tainha & Mugil spp. \\
Tambaqui & Colossoma macropomum (CUVIER) \\
Traíra & Hoplias malabaricus (BLOCH) \\
Tucunaré & Cichla spp. \\
Tucunaré-pitanga & Cichla monoculus (AGASSIZ) \\
Zebra pleco & Hypancistrus zebra (ISBRÜCKER \& NIJSSEN) \\
\hline
\end{tabular}




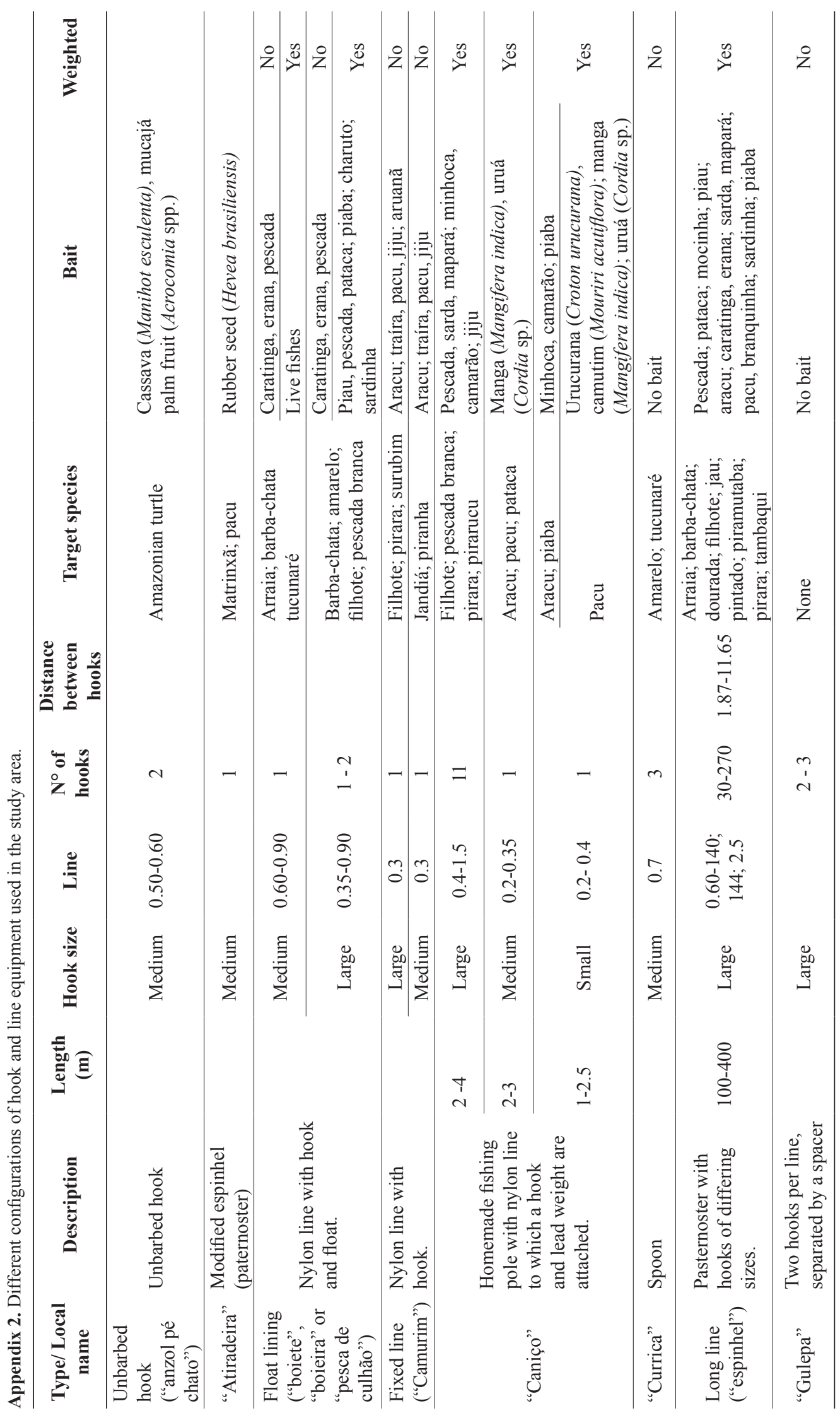


Mesquita, EMC. and Isaac-Nahum, VJ.

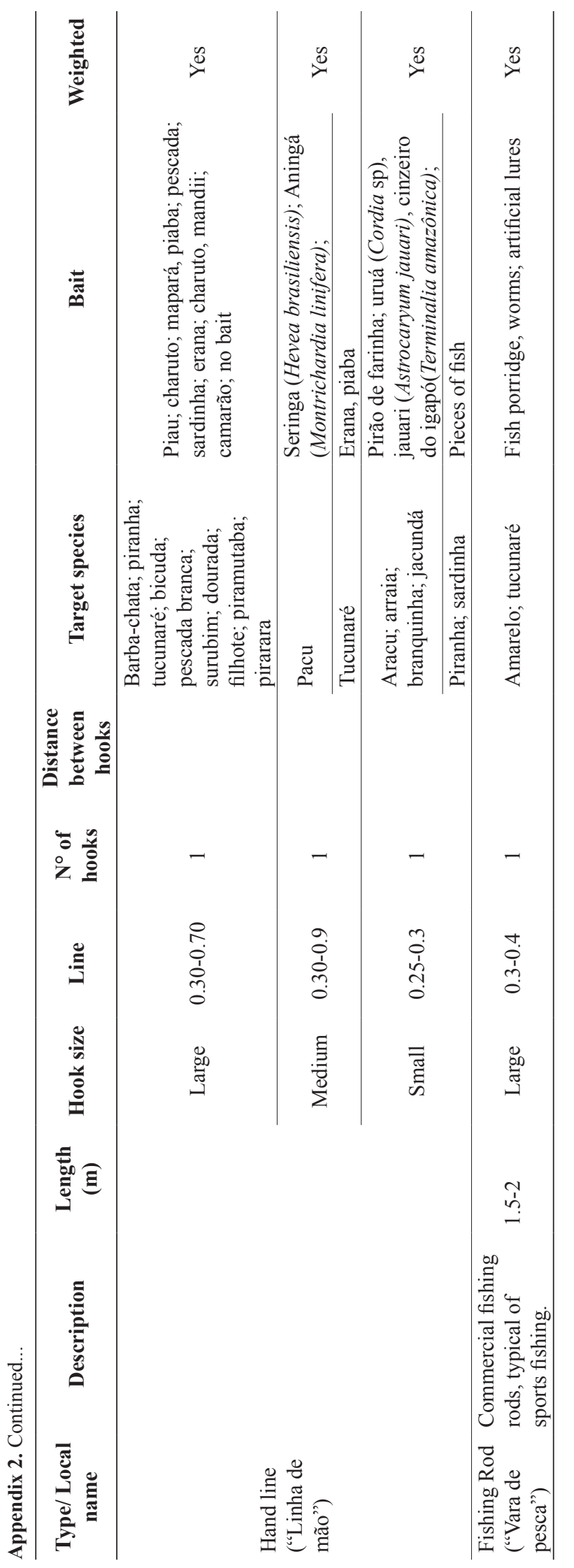




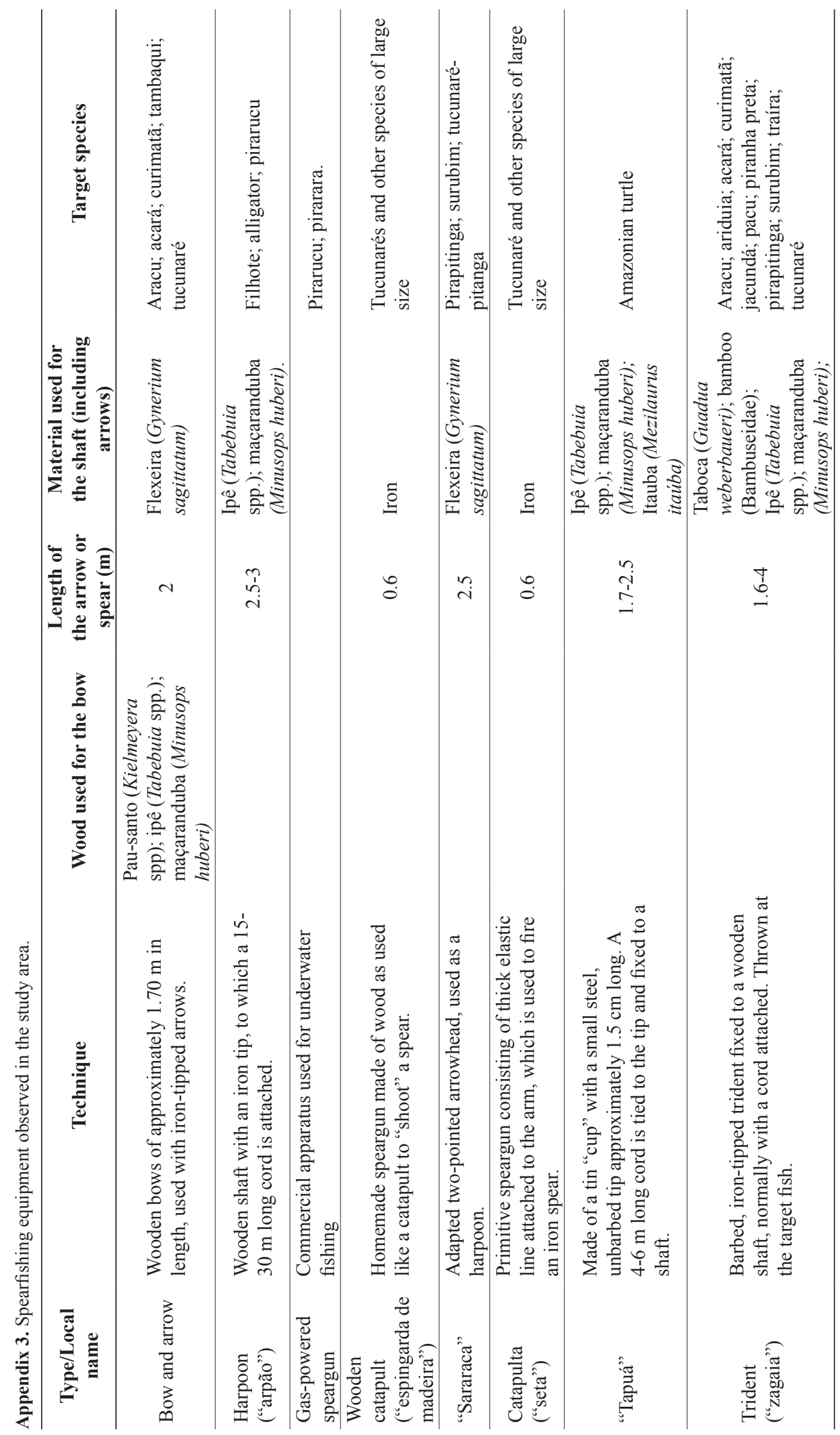




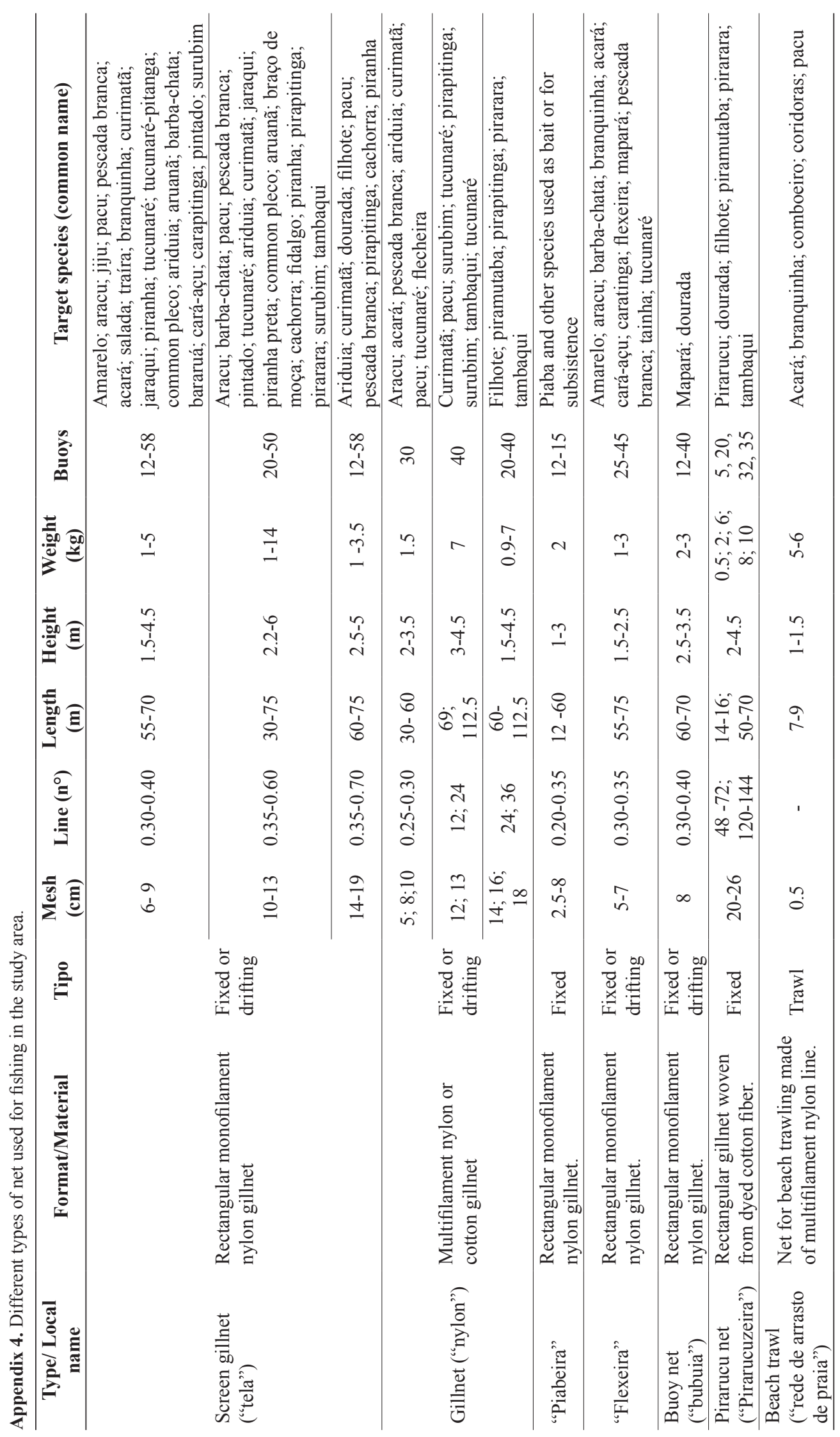




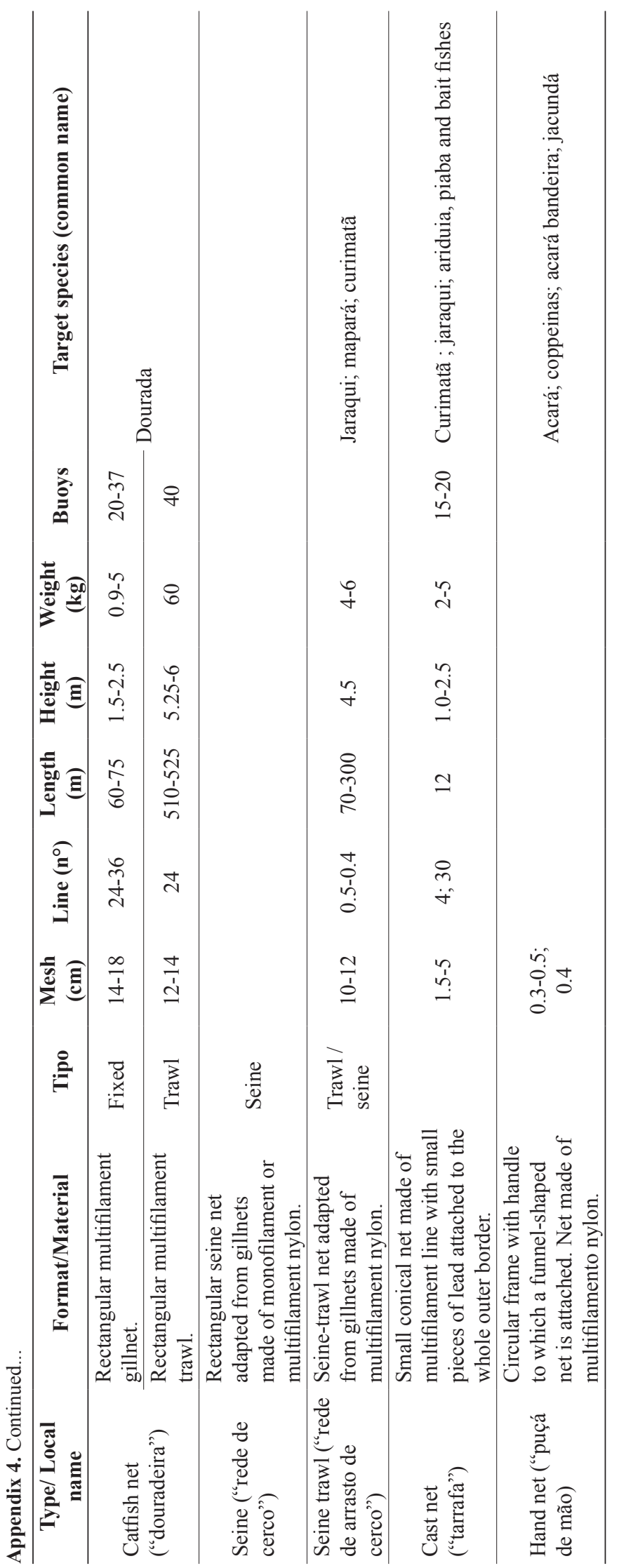

